\title{
STUDIES ON HUMAN PROTEINURIA. II. SOME CHARACTERISTICS OF THE GAMMA GLOBULINS EXCRETED IN NORMAL, EXERCISE, POSTURAL, AND NEPHROTIC PROTEINURIA *
}

\author{
By E. McKAY $\dagger$ ANd R. J. SLATER $\ddagger$ WITH THE TECHNICAL ASSISTANCE OF \\ BARBARA BROWN \\ (From the Research Institute of the Hospital for Sick Children, Toronto, Canada)
}

(Submitted for publication December 11, 1961 ; accepted May 3, 1962)

The presence in normal urine of small amounts of protein (1), some of which might originate in the urinary tract (2), was suspected toward the end of the last century. In 1951 Rigas and Heller (3) found the total 24-hour output of protein to be $39 \mathrm{mg}$, and since then estimations of up to $150 \mathrm{mg}$ per 24 hours have been made (4). Part of this protein is derived from the urinary tract (5) and part from the serum (6-11), from 14 and 20 serum components being found by immunoelectrophoresis (10).

Differences between the $\gamma$-globulin components of the protein of normal urine and that of serum have been noted in recent years. Jahnke and Scholtan (12) suggested from ultracentrifugal studies of total urinary proteins that the $\gamma$-globulins excreted might be in the form of low molecular weight fragments, but it was not until recently that this was definitely proved by Webb, Rose and Sehon (13) and by Franklin (4). It has been found also that there are immunologic differences between serum and urine $\gamma$-globulins as shown by immunoelectrophoresis (6) and by the quantitative precipitin reaction (14).

Although the mechanism of postural proteinuria is still in doubt, much work has been carried out on the subject since the earliest descriptions which are attributed to Ulzmann (15). In studies of the proteins of postural proteinuria by paper electrophoresis (16), starch gel and immunoelectrophoresis (17), and by quantitative precipitin tests (14), the $\gamma$-globulin component appears to behave like that of normal serum.

* Supported by Grants from the Medical Research Council of Canada and the Department of National Health and Welfare.

$\dagger$ Present address: Royal Children's Infirmary, Aberdeen, Scotland.

$¥$ Present address : College of Medicine, University of Vermont, Burlington, Vt.
Exercise proteinuria was noted in 1878 by von Leube (18), who found that of 119 soldiers whose early morning urine had been albumin-free, 14 developed proteinuria after arduous duty marches or battalion drill. Since then, numerous examples of exercise proteinuria have been recorded. Stewart (2) studied the condition in soldiers during fatigue; Blake and Larrabee (19) made observations on long distance runners; Collier (20) reported on athletes, especially rowing teams; and in a review of the subject in 1931, Volhard (21) records its occurrence in football players, cyclists, skiers, swimmers, wrestlers, racing walkers, boxers, and gymnasts. The term "athletic pseudonephritis" was coined by Gardner (22) to stress similarities between the urine of acute glomerulonephritis and that which followed physical exertion. In paper electrophoretic studies of exercise proteinuria Nebdal and Seliger (23) found striking correspondence between the protein fractions in serum and urine. The $\gamma$-globulins appear to be similar by this technique, but quantitative precipitin reactions (14) using an antiserum against serum $\gamma$-globulin show a definite difference between the $\gamma$-globulins of serum and exercise urine.

The purpose of the present study is to investigate, by immunoelectrophoresis, variations in the amount and characteristics of the urinary $\gamma$-globulins in physiological and pathological conditions.

\section{MATERIALS AND METHODS}

Terminology. A confusing nomenclature has been used to describe the condition of "postural" proteinuria. Since there may be variations in the proteins excreted in the urine of these subjects under different circumstances, it is advisable that terminology be precisely defined. In the present article we shall use the name "postural" to include all variants of the condition, "lordotic" for periods in extreme lordosis, and "orthostatic" for the proteinuria 
which occurs during normal diurnal activity in these subjects.

Urines. Normal urine was obtained from four healthy males, aged 25 to 35 years. Lordotic proteinuric urine was obtained from five healthy boys, aged 7 to 12 years, and from one healthy girl aged 15 years, none of these having history or evidence of renal disease. The urine was collected by spontaneous voiding after 10 minutes of erect lordosis. Subjects used for the study of exercise proteinuria were healthy male university students who were members of a swimming team. Urine specimens were obtained from them before and at an interval of 15 to 30 minutes after strenuous training lasting 1 to 3 hours with brief intermissions. Since the swimming bath was heated to $76^{\circ} \mathrm{F}$, the proteinuria which occurred cannot be attributed to the effects of cold, as in Johnson's cases (24). Swimmers whose pre-exercise specimen showed proteinuria were excluded from the study. Serial 24-hour urines were collected also from children with idiopathic nephrosis during progress from relapse to remission while on steroid therapy.

Electrophoretic and immunoelectrophoretic comparisons were carried out on individual urines as well as on pooled specimens. For further studies the $\gamma$-globulin component was isolated from pooled specimens of normal and exercise urines from several subjects, and from pooled lordotic specimens from the same girl. Thymol and sodium azide were used as preservatives and all urine specimens were stored in the cold at $4^{\circ} \mathrm{C}$.

Concentration of urinary proteins and isolation of $\gamma$-globulin. Protein concentration of urines was estimated by the biuret method. Specimens used as a source of $\boldsymbol{\gamma}$-globulin were filtered and the protein was precipitated by ammonium sulfate ( $650 \mathrm{~g}$ per $\mathrm{L}$ ) according to the method used by Franklin (4). After removal by centrifugation in a refrigerated centrifuge at approximately $1,800 \mathrm{G}$ for 1 hour, the precipitate was dialyzed against running tap water followed by distilled water until it was free of salts; the solution was then concentrated by dialysis against 40 per cent polyvinylpyrrolidone.

Preparative electrophoresis of the urinary protein concentrates was carried out in starch according to the method of Kunkel and Slater (25). The zones of $\boldsymbol{\gamma}$-globulin and transferrin were located by capillary interface tests, using unispecific antisera by the criteria of immunoelectrophoresis. The $\beta, \gamma$ - and $\gamma$-globulin segments of the block were eluted by displacement filtration with saline. The eluates were dialyzed in Visking tubing against distilled water at $4^{\circ} \mathrm{C}$ until they were free of salts, after which the protein was lyophilized.

Diethylaminoethyl (DEAE) cellulose columns were prepared according to the method of Jackson, Farmer, Slater and DeWolfe (26). Chromatography of the urinary $\gamma$ - and $\beta, \gamma$-globulin fractions was carried out, using a gradient of decreasing $\mathrm{pH}$ and increasing salt concentration, so that all the $\gamma$-globulin was eluted from the column before the sodium chloride gradient commenced. The $\mathrm{NaH}_{2} \mathrm{PO}_{4}$ concentration of $0.005 \mathrm{M}$ in the starting buffer was maintained until $50 \mathrm{ml}$ of eluate had been collected, after which the concentration rose steadily to reach $0.05 \mathrm{M}$ at $250 \mathrm{ml}$. Buffer salts were removed from the effluent fractions by dialysis in the cold against distilled water, and the protein was again lyophilized.

Paper, starch gel, and immunoelectrophoresis. For comparative purposes a small pool of exercise urine was divided into two parts; one part was concentrated by dialysis against polyvinylpyrrolidone and the other by ultrafiltration using $8 / 32$ inch Visking tubing and a negative pressure of $350 \mathrm{~mm}$ of mercury. We have found that these conditions of ultrafiltration provide protein-free filtrates even when concentrating moieties of $\boldsymbol{\gamma}$-globulin as small as approximately 15,000 molecular weight. As a further control on the influence of $\left(\mathrm{NH}_{4}\right)_{2} \mathrm{SO}_{4}$ precipitation on the $\gamma$-globulin, a 72 -hour pool of normal urine was concentrated by ultrafiltration. All nephrotic urines were concentrated by this method. Individual specimens of exercise proteinuric urines were concentrated directly by dialysis against polyvinylpyrrolidone without preliminary precipitation of the protein. All urines were then adjusted to a final protein concentration of approximately 7 to $8 \mathrm{~g}$ per $100 \mathrm{ml}$.

Paper electrophoresis was carried out in barbital buffer, $\mathrm{pH}$ 8.6, ionic strength 0.1 . For quantitation, $30-\mu \mathrm{l}$ aliquots of urine concentrates were applied, and the electrophoretic strips were stained with Lissamine green and scanned photoelectrically.

Immunoelectrophoresis was carried out in 1.5 per cent agar gel on $25 \times 75 \mathrm{~mm}$ glass microscope slides, by modification of Scheidegger's (27) micro method. Wieme's (28) technique, which uses a steep voltage gradient and a cooling liquid, was employed for the electrophoretic separation, and the antiserum was applied on a $2-\mathrm{mm}$ wide filter paper strip laid on the surface of the gel. Diffusion was continued for 48 hours, the slides were washed in saline for 3 days, and then stained with Ponceau $S$ and photographed.

Antisera. Four different antisera against whole human serum were used: Institut Pasteur equine antiserum no. 13411; Hyland Laboratories goat antiserum, lot 3802 R.L.; and 2 antisera ${ }^{1}$ (A and B) prepared in goats. Four rabbit antisera $\left(\gamma_{a}, \gamma_{b}, \gamma_{c}, \gamma_{d}\right)$ were prepared against human serum $\gamma$-globulin isolated by Cohn fractionation followed by zone electrophoresis in starch.

\section{RESULTS}

Quantitation of protein excretion. Comparisons were made of the rate of protein excretion in the urine, during normal activity, during and immediately after exercise, and in subjects with orthostatic proteinuria (Table I). In 24 normal subjects of all ages studied in this laboratory, the average 24hour output of protein in the urine was $52 \mathrm{mg}$.

Of the 96 swimmers examined, 25 ( 36 per cent) had proteinuria before swimming. ${ }^{2}$ Whether these

\footnotetext{
${ }^{1}$ Kindly donated by Dr. Clark West, Cincinnati, Ohio.
} 2 Demonstrated by a positive sulfosalicylic acid reaction. 
TABLE I

Protein excretion in urine*

\begin{tabular}{|c|c|c|c|}
\hline & Concentration & $\begin{array}{l}\text { Rate of } \\
\text { excretion }\end{array}$ & $\begin{array}{c}\text { Albumin / } \\
\text { globulin } \\
\text { ratiot }\end{array}$ \\
\hline \multirow{2}{*}{$\begin{array}{l}\text { Normal } \\
\text { (24 subjects) } \\
\text { Range }\end{array}$} & $\begin{array}{c}m g / m l \\
0.07\end{array}$ & $\begin{array}{c}m g / m i n \\
0.04\end{array}$ & \multirow[t]{2}{*}{0.4} \\
\hline & $0.01-0.14$ & $0.007-0.1$ & \\
\hline $\begin{array}{l}\text { Exercise } \\
\text { (42 subjects) }\end{array}$ & Max. 3.4 & Max. 5.1 & 1.1 \\
\hline \multirow{2}{*}{$\begin{array}{l}\text { Postural } \\
\text { (6 subjects) }\end{array}$} & $\begin{array}{l}\text { Normal max. } 1.6 \\
\text { activity }\end{array}$ & Max. 0.9 & \\
\hline & $\begin{array}{l}\text { Extreme max. } 3.7 \ddagger \\
\text { lordosis }\end{array}$ & Max. 4.88 & 1.75 \\
\hline
\end{tabular}

* Protein concentration and excretion rates for exercise and postural urines have been expressed as maximal values only since all gradations down to normal were found.

$+\mathrm{A} / \mathrm{G}$ ratios were calculated from paper electrophoretic patterns of normal, 6 exercise, and 5 postural urines.

$\ddagger$ Concentrations up to $33.8 \mathrm{mg} / \mathrm{ml}$ have been obtained in the labor-

atory.

laboratory.

subjects had postural proteinuria or had previously exercised sufficiently to develop proteinuria was not determined. Of the remaining 44, 42 (95 per cent) developed proteinuria. Protein excretion varied widely in these subjects up to a maximum of $5.1 \mathrm{mg}$ per minute. Details of the time of maximal protein excretion and of variations in relation to rate and duration of swimming will be reported elsewhere. Similarly, wide variations were noted in postural proteinuria, with excretion rates up to $0.9 \mathrm{mg}$ per minute during normal activity; collections were made over approximately 12-hour diurnal periods. During short periods in extreme lordosis, the same subjects excreted up to $4.8 \mathrm{mg}$ per minute. Previous studies have revealed transient excretion rates as high as $30 \mathrm{mg}$ per minute (14).

Fractionation by electrophoresis and chromatography. In paper electrophoresis patterns of urinary proteins, shown in Figure 1 as original patterns and as photometric scans, components corresponding to the five main serum components are not always clearly differentiated. Furthermore, there was considerable variation in each group between individual subjects. The albumin band is usually clear, but the globulins are often indistinct,
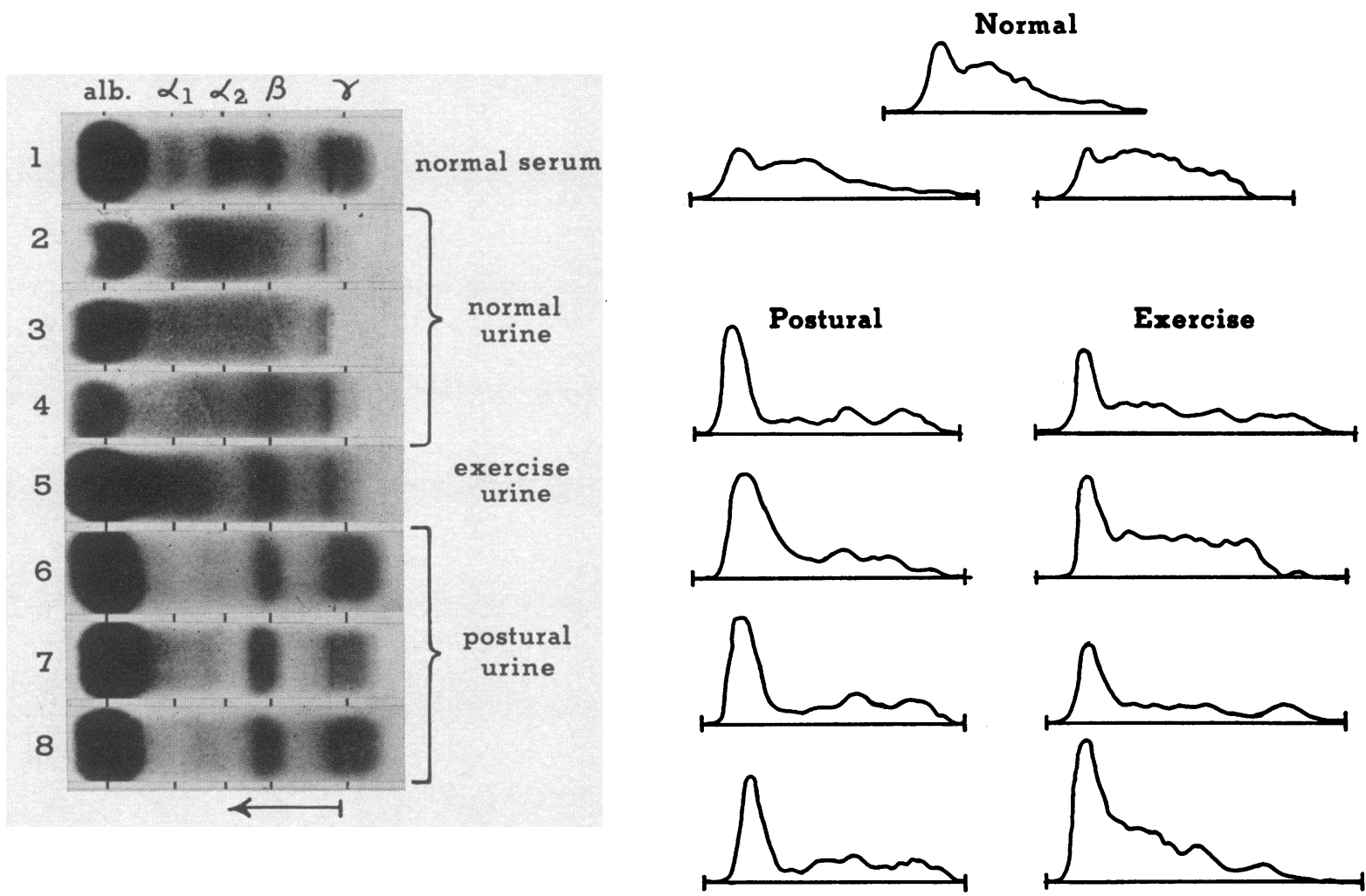

Fig. 1. PAPER EleCtrophoretic PATterns OF URINARY PROTEINS EXCRETED UNDER "PhySiOLOGIC" conditions. The photoelectric scan patterns do not coincide with the paper patterns. Noteworthy are not only the group differences but also the individual variations. 

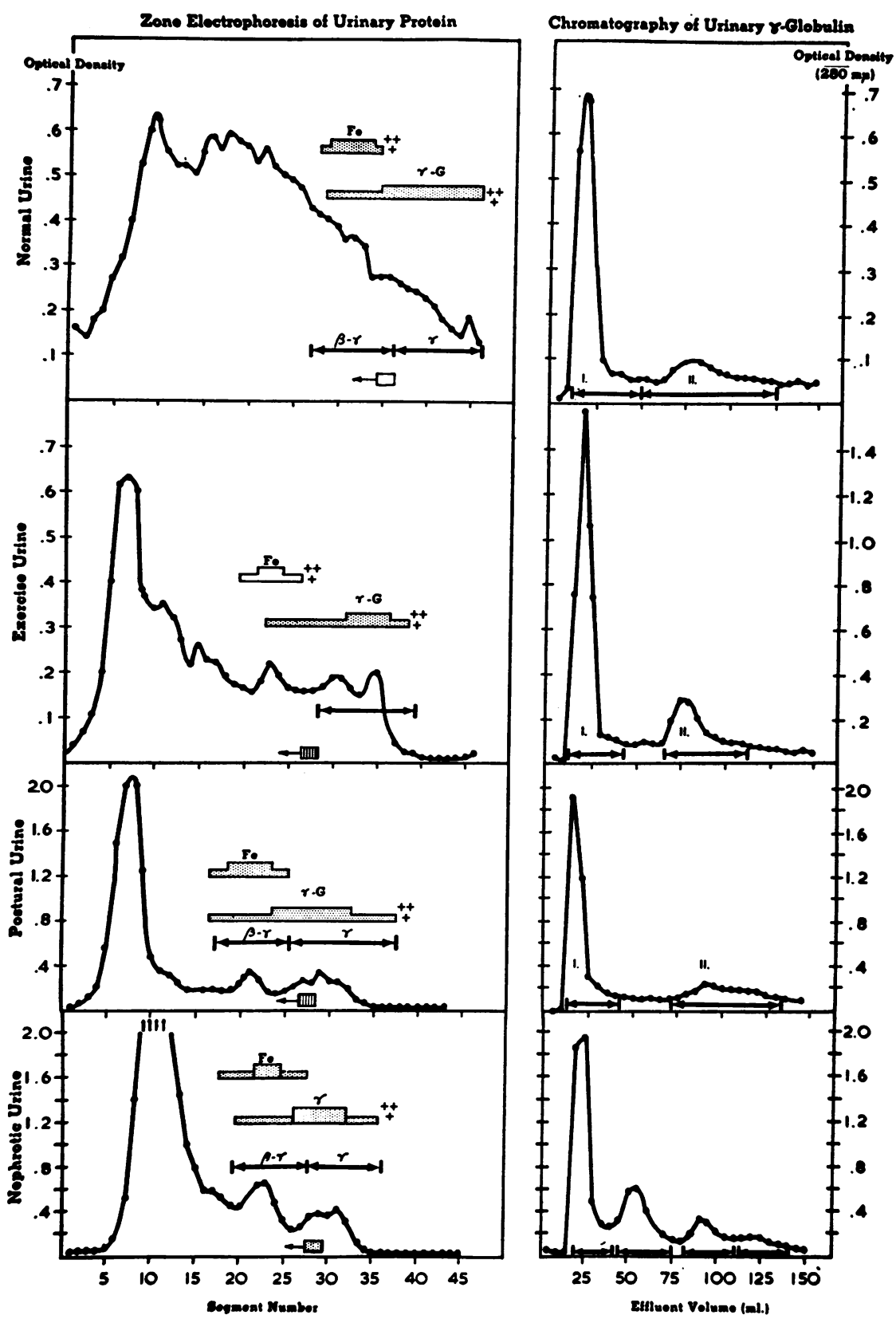

Fig. 2. Preparative separations of the URINARy $\gamma$-globulin and DEAE PATTERNS. The zone of localization of $\gamma$-globulin and transferrin $(\mathrm{Fe})$ in the electrophoretic separations were defined with antiserum and the relative concentrations noted as + .

especially in the $\alpha_{1}$ - and $\alpha_{2}$-regions. As noted by others, the amount of globulins relative to albumin in normal urine was high, whereas in postural urines the reverse ratio was seen, and about equal amounts of albumin and globulins were present in exercise urine (Table I). Differentiation into components comparable to serum was clearest in lordotic urines and least distinct in normal urine, where definition was so indistinct as to make quantitation of separate components, other than albumin, meaningless.

Preparative zone electrophoresis followed by 


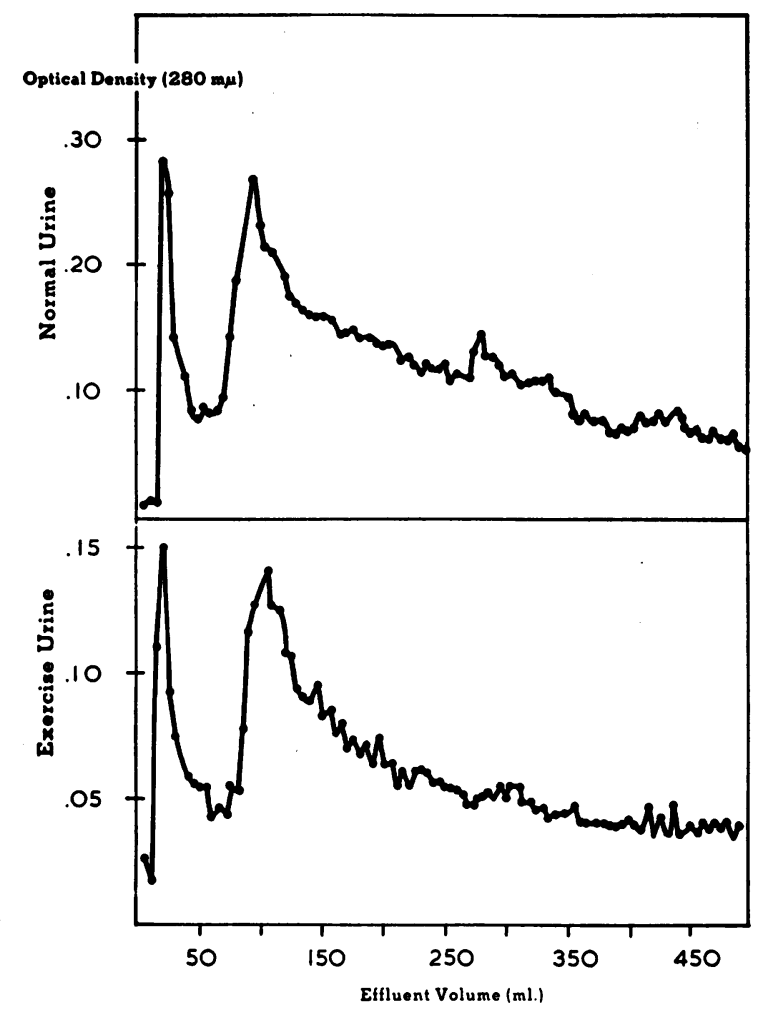

Fig. 3. DEAE chromatographic SEPARAtion of the $\beta, \gamma$-GLOBULIN REGION OF NORMAL AND EXERCISE URINARY PROTEIN.

DEAE chromatography of the eluted $\gamma$-globulin component was done in order to compare the $\gamma$-globulins excreted in the differing circumstances. Figure 2 illustrates that although normal, exercise, and postural urinary protein contain differing proportions of the protein components, the $\gamma$-globulin from each separated into two main peaks on the DEAE column. The properties of these will be reported elsewhere. In contrast, the $\gamma$-globulin separated from nephrotic urinary protein revealed three distinct peaks : an intermediate peak in the eluate region 50 to 60 in addition to the two peaks noted in the "physiologic" urinary $\gamma$-globulin. A small peak at the eluate 125 region represents a possible fourth constituent in trace amounts.

Since special interest attached to the difference between exercise and "normal" urinary protein, the electrophoretic $\beta, \gamma$-regions also were compared by DEAE fractionation. Figure 3 reveals that no difference in the relative proportion or elution rate of the two peaks was apparent. The first peak, in the eluate region of $40 \mathrm{ml}$, reacted with $\gamma$-globulin antiserum; the second, in the eluate region of $100 \mathrm{ml}$, reacted with transferrin antiserum.

Immunoelectrophoresis. Immunoelectrophoretic patterns of the urinary proteins have been studied with particular reference to the $\gamma$-globulin component. Figure 4 shows typical examples of the patterns obtained with an antiserum against whole human serum. It is evident that the $\gamma$-globulin precipitin line is single (or minimally split at each extremity) for normal serum and lordotic urine, but double, and in some instances triple, and shortened for normal and exercise urines, depending upon the particular antiserum used. These differences have been confirmed with two other normal urines, with seven exercise urines (Figure 5), and with six lordotic or orthostatic urines from five subjects (Figure 6). In the last group, the

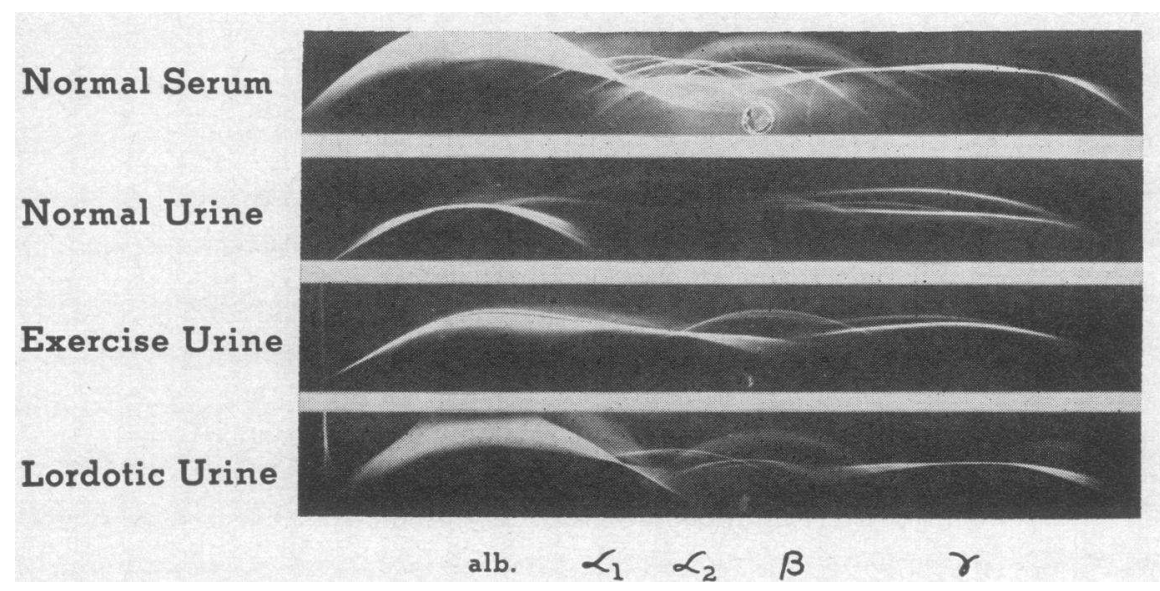

Fig. 4. IMMUNOELECTROPHORESIS OF NORMAL SERUM AND PHYSIOLOGICAL PROTEINURIAS, WITH GOAT B ANTISERUM TO WHOLE HUMAN SERUM. 


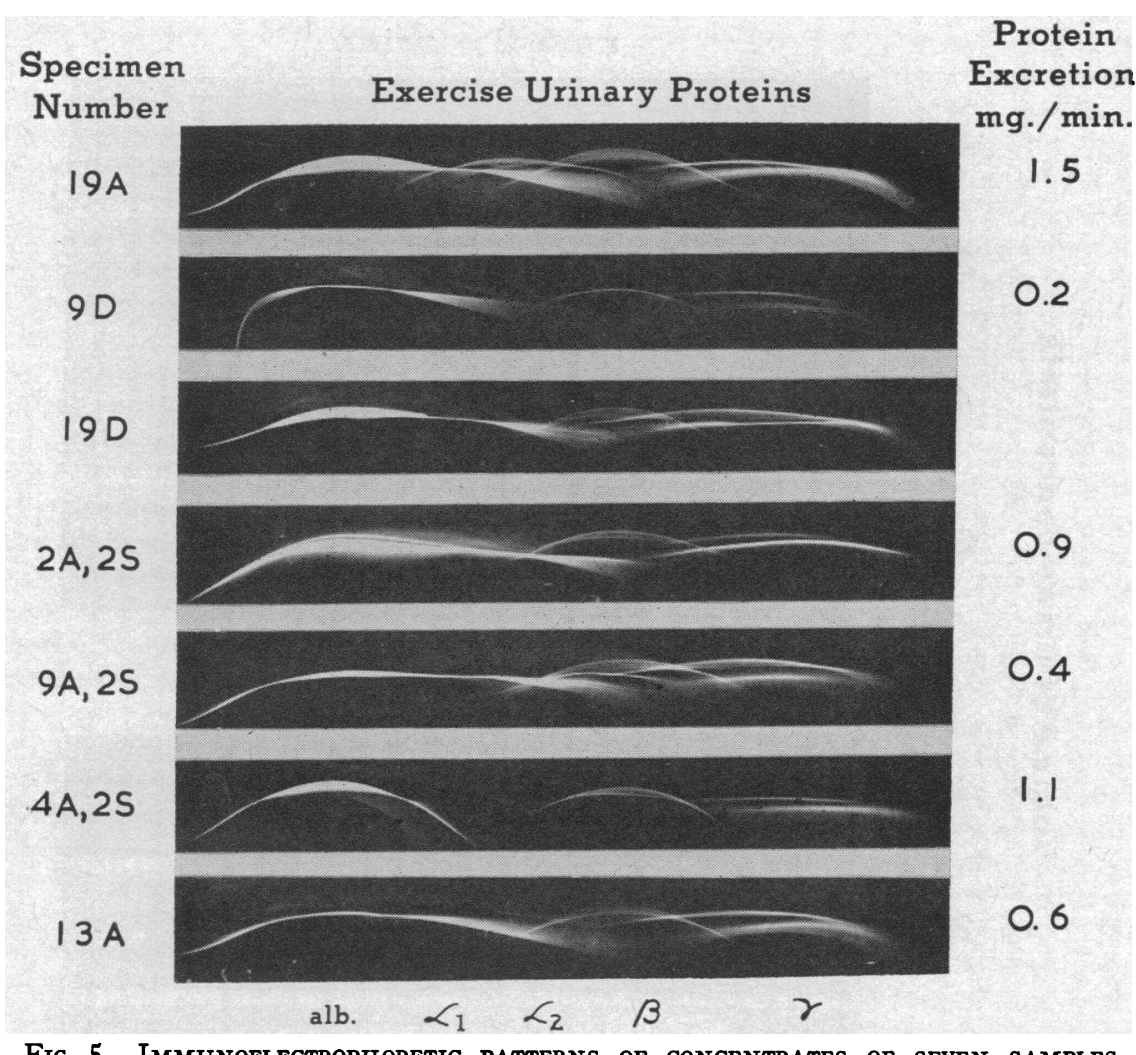

Fig. 5. IMMUNOELECTROPHORETIC PATTERNS OF CONCENTRATES OF SEVEN SAMPLES FROM DIFFERENT SUBJECTS OF EXERCISE PROTEINURIC URINE WITH GOAT B ANTISERUM To WhOLE HUMAN SERUM. In all cases, the $\gamma$-globulin precipitin line is double.

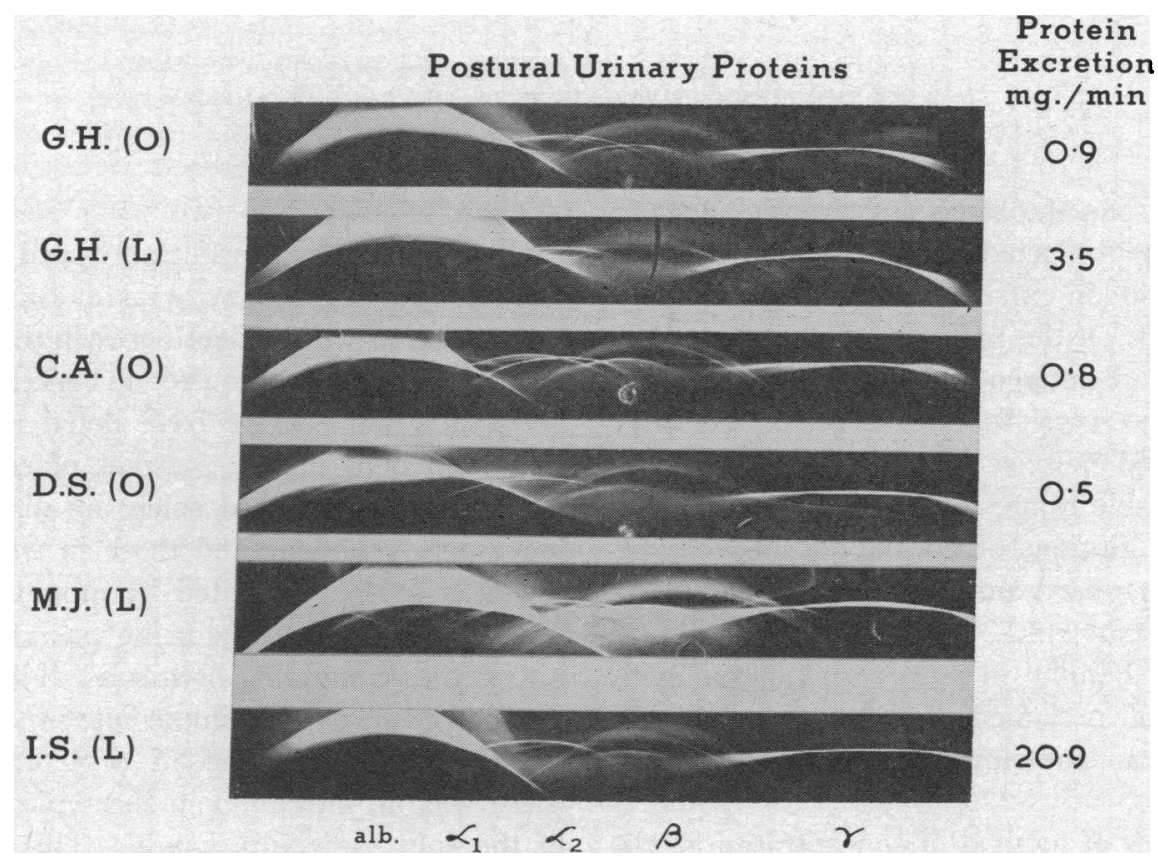

FIg. 6. IMMUNOELECTROPHORETIC PATTERNS OF CONCENTRATES OF SIX SAMPLES OF POSTURAL PROTEINURIC URINE WITH GOAT B ANTISERUM TO WHOLE HUMAN SERUM. In all cases, the $\gamma$-globulin pricipitin line is single. $O=$ orthostatic, urine collected during normal activity. $\mathrm{L}=$ lordotic, urine collected after lordotic posturing. 


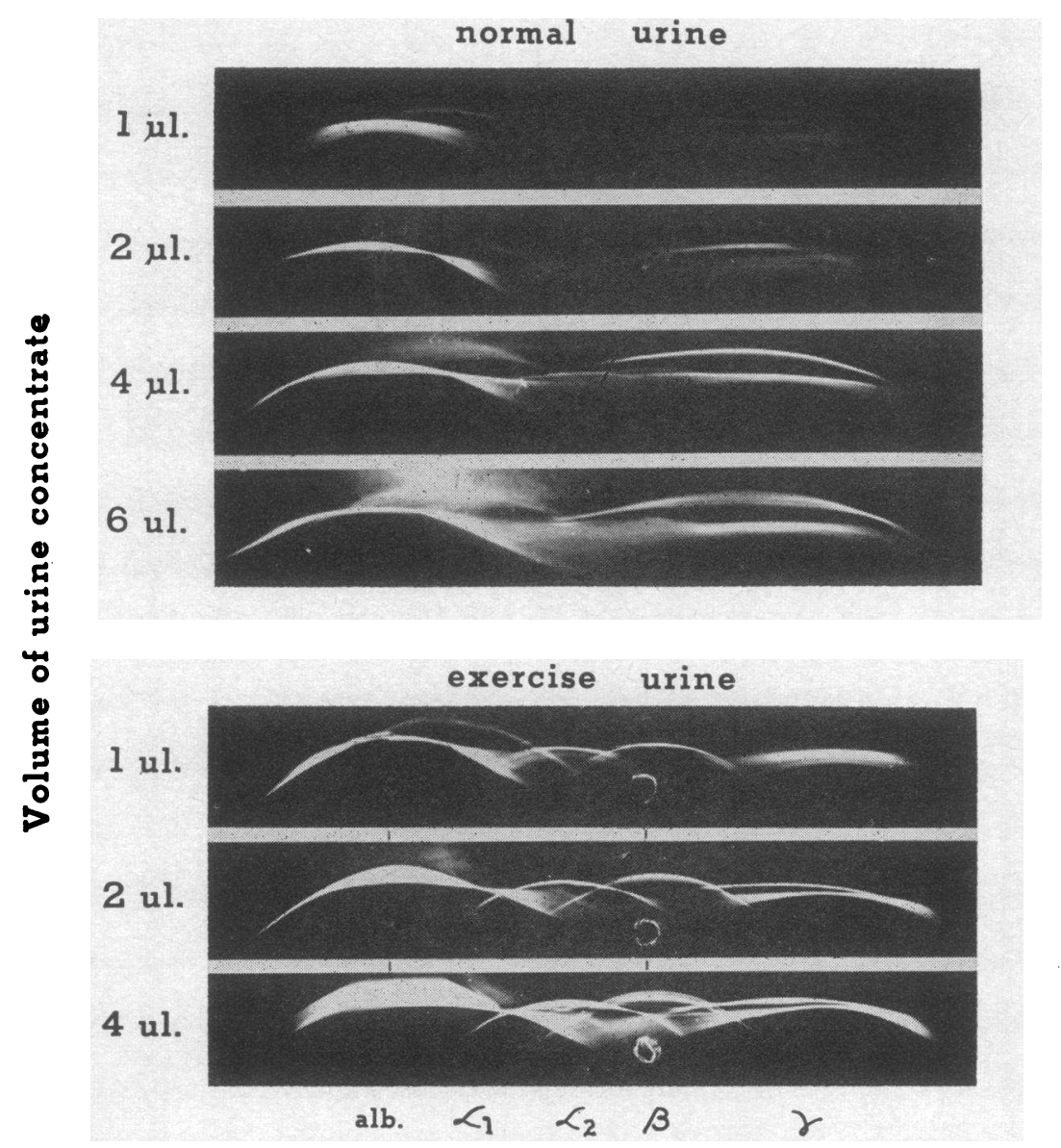

Fig. 7. IMMUNOELECTROPHORESIS OF NORMAL AND EXERCISE PROTEINURIC CRINES SHOWING THE EFFECT OF VARIATIONS IN THE RATIO OF ANTIGEN AND ANTISERUM. (Goat B antiserum to whole human serum.)

$\gamma$-globulin line has the same appearance whether the urines were collected during normal activity or during periods in extreme lordosis.

The influence on the precipitin lines of varying the proportion of antigen and antibody was tested (Figure 7), and it was found that the double lines with normal and exercise urine persisted throughout a considerable range of antigen concentration. Furthermore, dilutions of normal serum were set up against a standard amount of antiserum (Figure 8, upper 5 patterns). Although the $\gamma$-globulin precipitin line became indistinct and broad, with an "onion skin" or lamellar appearance at higher dilutions, it was not similar to that seen in the urine patterns.

The influence of method of concentration of the urinary proteins on the immunoelectrophoretic pattern was investigated by dividing a small pool of exercise urine into two parts and by concentrating one part by ultrafiltration and the other by dialysis against polyvinylpyrrolidone. No significant variation was evident between the electrophoretic patterns of the two protein concentrates (Figure 8). Similarly, we have noted no significant difference between the patterns of exercise urine specimens concentrated solely by dialysis against polyvinylpyrrolidone and those in which the protein was first precipitated by ammonium sulfate.

In fact, when exercise urine was voided directly into bottles containing both solid $\left(\mathrm{NH}_{4}\right)_{2} \mathrm{SO}_{4}$ and $\mathrm{HgCl}_{3}$, thus providing immediate precipitation and presumably inactivation of proteolytic enzymes, there was no alteration in the typical appearance of the split $\gamma$-globulin bands. This confirms the unpublished observations of Stevenson (29).

Variations in the reactivity of the $\gamma$-globulins of 
both serum and urine with different antisera were studied. When normal serum reacted with eight different antisera, as shown in Figure 9A, the $\gamma$-globulin precipitin line appeared single with the first five antisera, but showed minimal splitting with $\gamma_{b}, \gamma_{c}$, and $\gamma_{d}$. Similarly, the postural urine patterns in Figure 10B showed apparently single $\gamma$-lines throughout. In contrast, the normal urinary $\gamma$-globulin (Figure 9B) developed double lines with $\mathrm{A}, \mathrm{B}$, and Pasteur antisera, slight splitting with $\gamma_{a}$, triple lines with $\gamma_{b}, \gamma_{c}$, and $\gamma_{\mathfrak{a}}$, and $a$ single line with Hyland antiserum. Figure 10A illustrates that the exercise urinary $\gamma$-globulin reacted to produce double lines with all antisera except $\gamma_{a}$ (a weak antiserum). These immunoelectrophoretic patterns, developed with eight different antisera, demonstrate that the variations between the $\gamma$-globulin precipitin lines of different urines are not a function of one particular anti- serum, although certain antisera show the variations much more clearly than others.

In studies of exercise urine by the Ouchterlony technique we have found that, as in normal urine (4), the precipitin line nearest the point of application of antigen gives a reaction of identity with $7 \mathrm{~S} \gamma$-globulin. The more distant precipitin line of exercise urine gives a reaction of identity with a similar band of normal urine. A third band in normal urine, most distant from the origin of the antigen, does not have a counterpart in exercise urine.

Figure 11 depicts an unusual variant of postural urinary $\gamma$-globulin on one occasion during lordosis by Patient I.S., the methods of preparation and analysis being similar to those used with other urines. Although the bands were poorly developed with Hyland and $\gamma_{a}$ antiserum, the presence of a fast and slow band uniting with the main $\gamma$-globu-

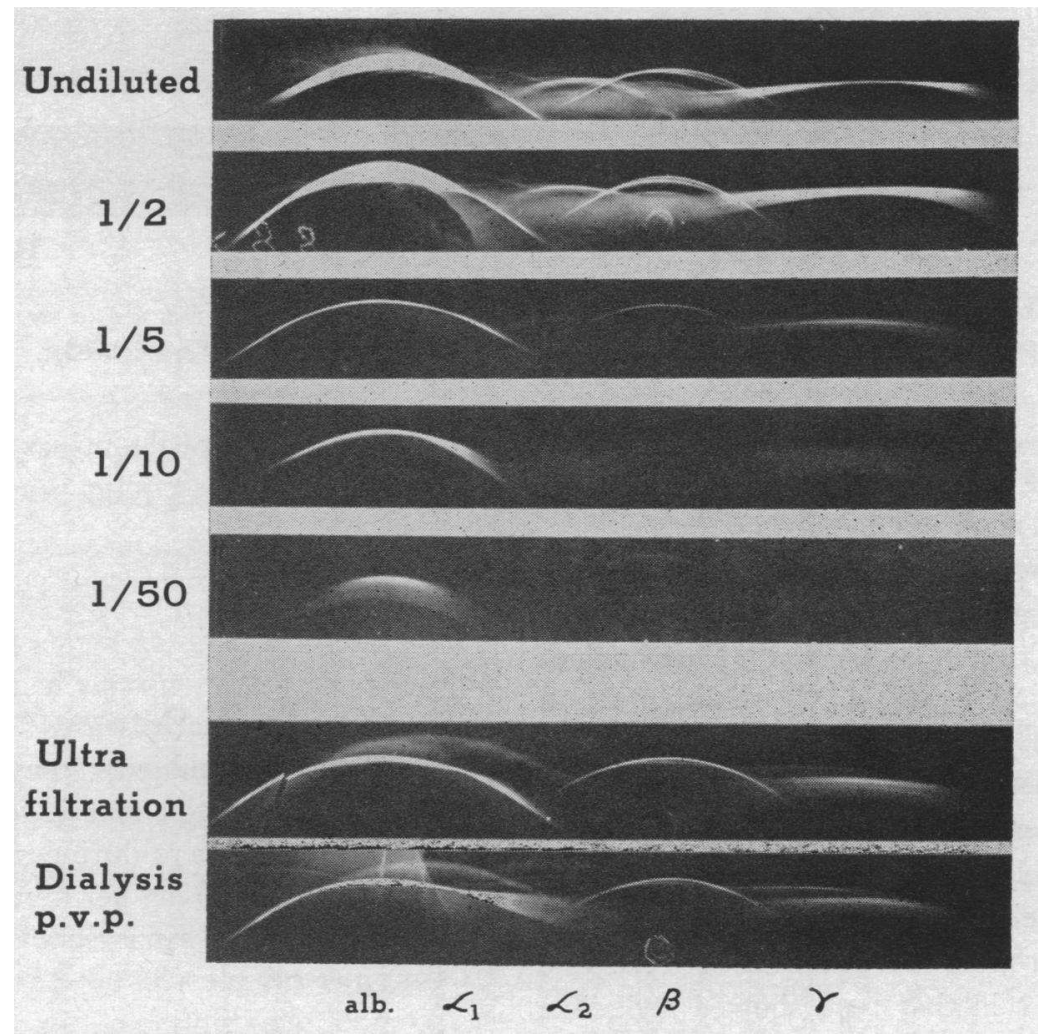

Fig. 8. IMMUNOELECTROPHORESIS OF DILUTIONS OF NORMAL SERUM USING A CONSTANT VOLUME OF ANTISERUM SHOWS VARIATIONS IN THE APPEARANCE OF THE $\gamma$-GLOBULIN AND ALBUMIN PRECIPITIN LINES IN CONDITIONS OF ANTIBODY EXCESS. The two lower patterns illustrate the effect of the method of concentration on immunoelectrophoretic patterns of exercise proteinuric urine. (Goat B antiserum to whole human serum.) 


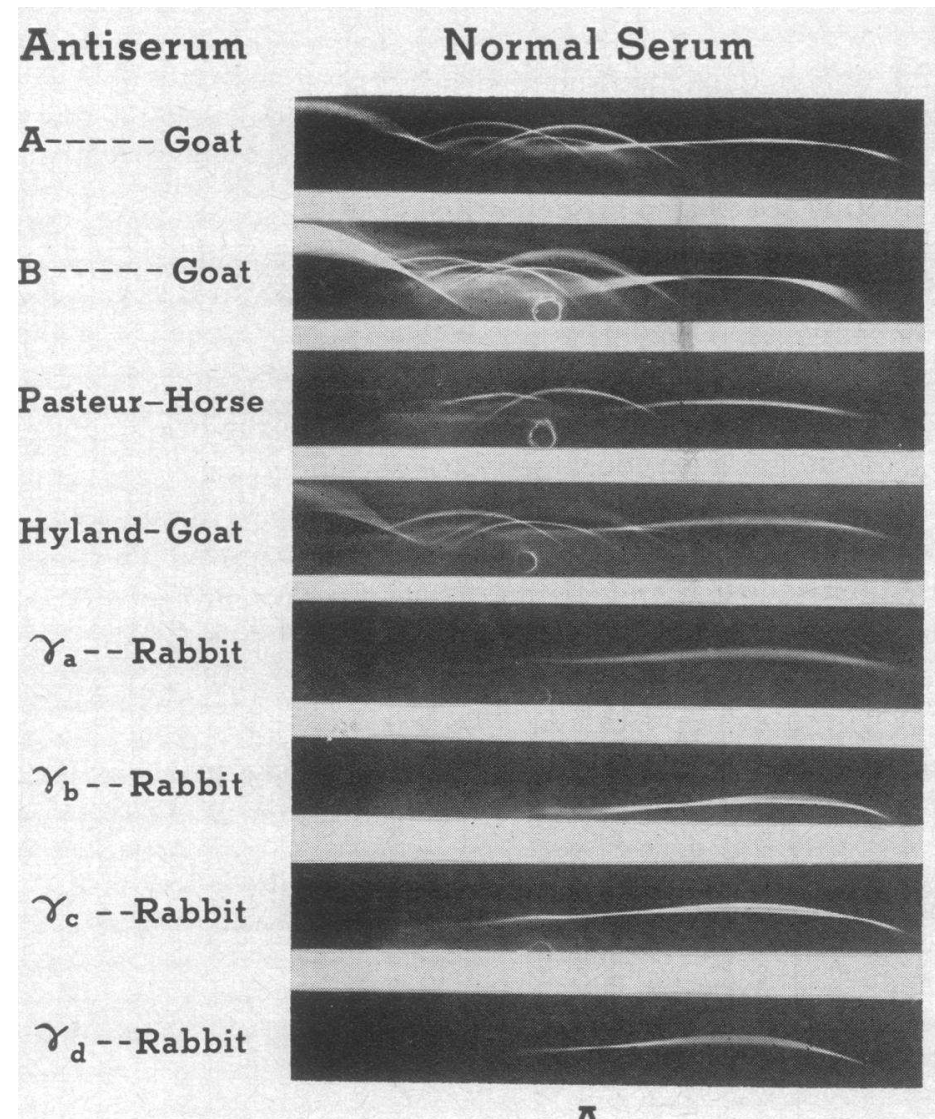

$\bar{A}$

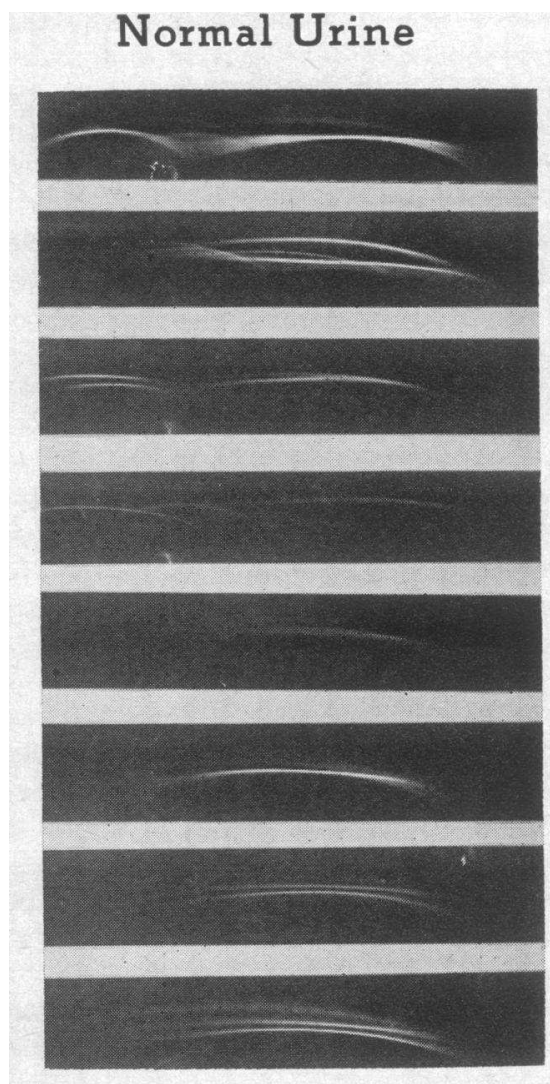

B

Fig. 9. IMMUNOELECTROPHORESIS OF PROTEINS OF NORMAL SERUM AND NORMAL URINE USING FOUR ANTISERA AGAINST WHOLE HUMAN SERUM AND FOUR ANTISERA AGAINST PURIFIED $\boldsymbol{\gamma}$-GLOBULIN.

lin line is quite clear. This has been observed in one other patient, a child with chronic nephritis complicated by a nephrotic syndrome.

Nephrotic urines. In Figure 12 are shown the patterns of nephrotic urines developed with whole serum antiserum and $\gamma_{b}$-antiserum. Each patient was studied during a period when his excretion of protein varied widely, and in the case of B.Z. as proteinuria disappeared, associated with progress to remission. The main feature was the presence of double $\gamma$-globulin bands even in the presence of proteinuria as great as 4 to $6 \mathrm{~g}$ per day. The electrophoretic patterns of P.B. and B.Z. were similar in that both showed a distinct fast and slow component, whereas the pattern of T.M. resembled those developed by normal and exercise urinary $\gamma$-globulin. At high rates of protein excretion, the amount of $\gamma$-globulin excreted by T.M. was relatively so small that even after concentration of the urinary protein to 7 to 8 g per $100 \mathrm{ml}$ the precipitin band was barely perceptible.

\section{DISCUSSION}

The rate of protein excretion in the urine under physiological conditions may be transiently as high as that seen in renal disease. Thus, certain apparently healthy subjects may excrete in the lordotic posture up to about 20 to $30 \mathrm{mg}$ of protein per minute, and others during swimming exercise may excrete about $5 \mathrm{mg}$ per minute. Normal subjects studied by the same techniques excrete about $0.04 \mathrm{mg}$ per minute ( $52 \mathrm{mg}$ per 24 hours).

Accurate quantitation of the rate of protein excretion during exercise and in lordosis is difficult because of the dead space of the collecting system, and comparisons between the two conditions are further complicated by the different time at which protein excretion occurs relative to the stressful 
stimulus. The rates of excretion presented in Table I for lordotic proteinuria are calculated from the amount of protein in urine collections made immediately after cessation of lordosis and referred to the time during which lordosis was maintained. This takes into account the observation made in previous studies (14) that protein is transferred from plasma to urine only during the period of lordosis, but it ignores the decreasing amount of protein which is thereafter washed out of the renal collecting system. The excretion rate should be calculated from the total time in lordosis and the total protein excreted from the beginning of posturing until excretion is again normal. The estimates in Table I thus are low.

A similar situation prevails in exercise proteinuria except that, as White and Rolf (30) have shown in runners, the proteinuria occurs during the period following exercise. Our findings in swimmers are similar, one young athlete showing no proteinuria on numerous occasions in the specimen of urine passed immediately after exercise.
His maximal rate of protein excretion occurred during the first 15 minutes after swimming, the rate returning to resting levels within 2 hours. Excretion rates in exercise proteinuria must therefore be calculated during this post-exercise period. The data in Table I were derived from swimmers undergoing strenuous exercise over a 1- or 2-hour period, the urine being collected from the commencement of exercise until approximately 30 minutes after its cessation; thus these values also will be low. For purposes of comparison, however, the significant feature is the overlap which occurs in rates of protein excretion between lordosis and exercise and renal disease.

The composition of the urinary protein as defined by paper electrophoresis varies considerably, with much better definition of distinct components when the protein is excreted in higher concentration. Poor definition of components in patterns of lesser and "normal" proteinuria is due largely to the higher relative concentration of other proteins, believed to be derived from the renal tract,

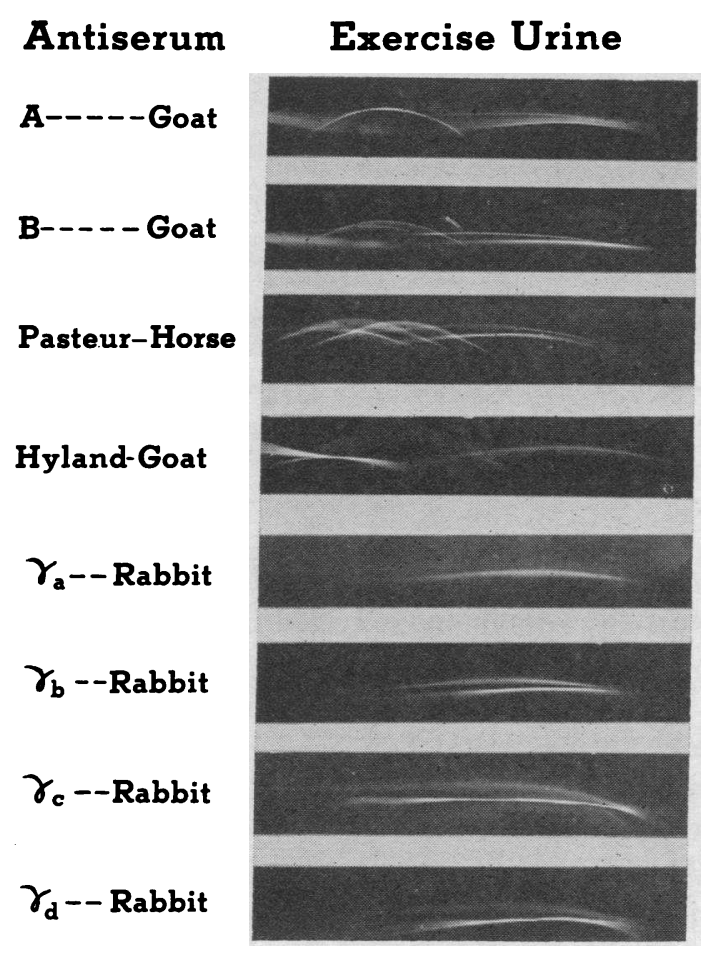

A

\section{Postural Urine}

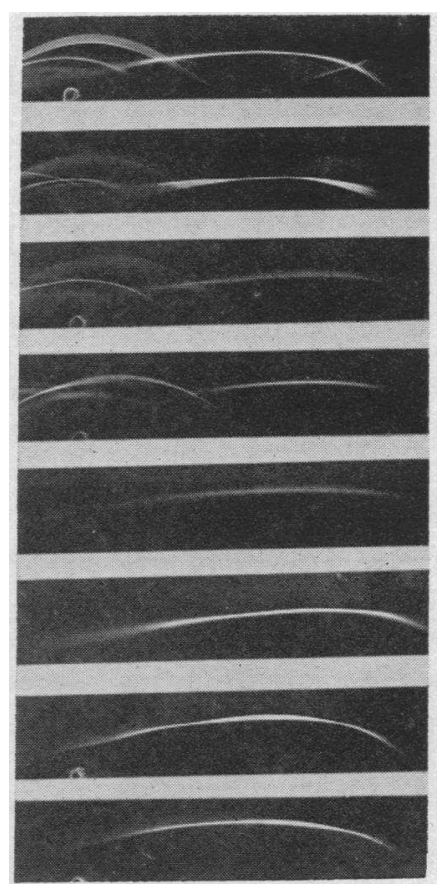

B

Fig. 10. IMMUNOELECTROPHORETIC PATTERNS OF PROTEINS OF EXERCISE AND POSTURAL URINE With the SAME ANTISERA AS IN The Figure 9 studies. Postural urinary protein is that of one subject, G.H., and was collected during lordosis. 


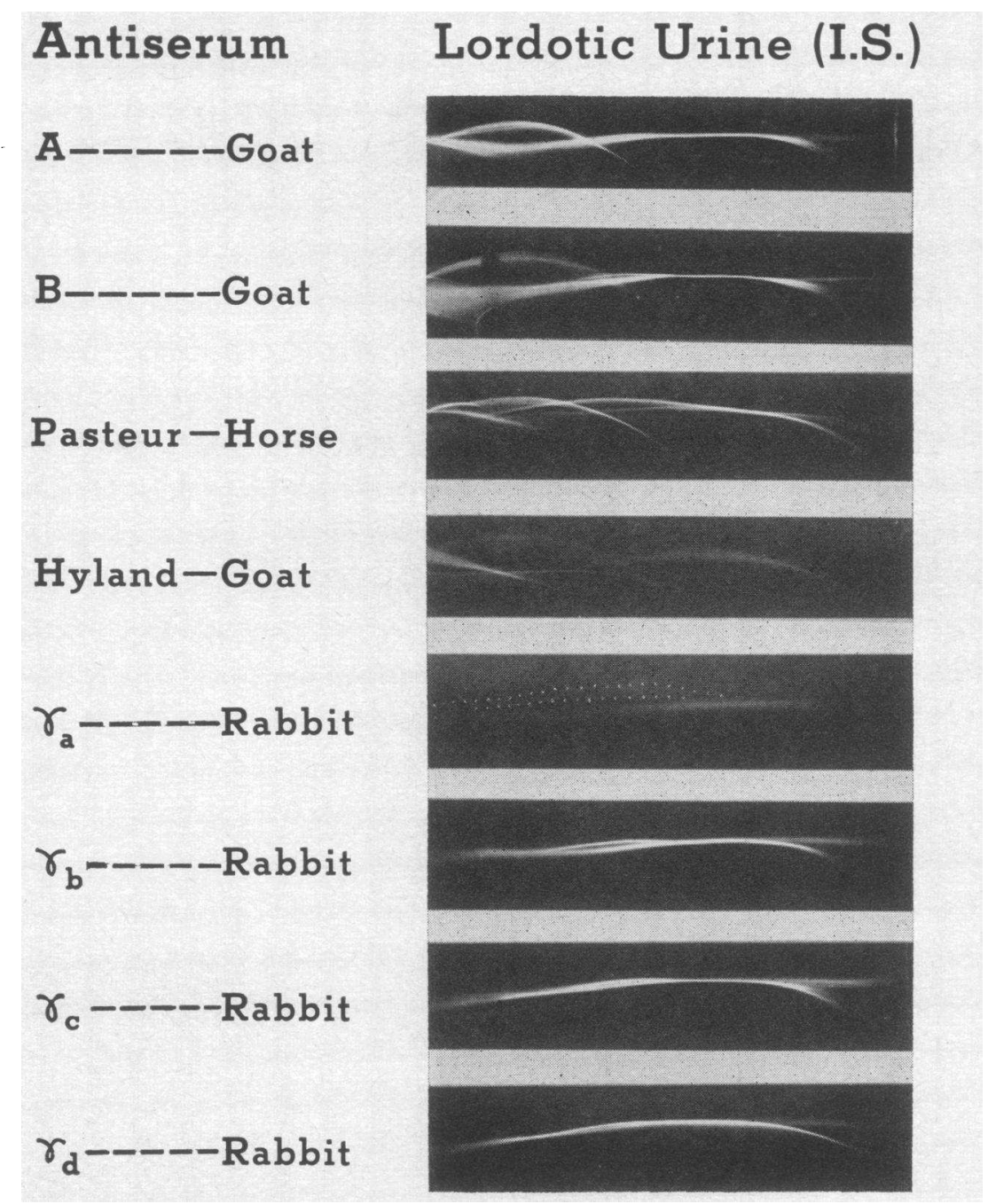

Fig. 11. IMMUNOELECTROPHORESIS OF LORDOTIC URINE (I.S.) WITH THE SAME ANTISERA AS IN Figures 9 and 10. The appearance of slow and fast splits in the gamma band were not seen in other proteins in this study, with one exception (see text).

which obscures the components derived by renal filtration from the plasma. Attempts to quantitate the urinary protein in comparison to the relative composition of serum may thus be misleading.

Previous observations in this laboratory showed that the $\gamma$-globulin excreted in exercise proteinuria reacted in quantitative precipitin tests in a manner similar to the minute amounts excreted in normal urine, in contrast to that of postural proteinuria which behaved like serum 7S $\gamma$-globulin (14). Exercise urinary $\gamma$-globulin gave a reaction of partial identity with 7S $\gamma$-globulin in the manner described by Webb and co-workers (13) and by Franklin (4) for the $\gamma$-globulin of normal urine.
In this study, the distinct differences between the $\gamma$-globulins excreted in the urine under different conditions have been demonstrated by immunoelectrophoresis. Three varieties of $\gamma$-globulin precipitin line have been found: single lines, parallel or almost parallel lines, and lines in series. Postural urines show a constant pattern with a clear-cut, single $\gamma$-line closely resembling that of normal serum. Normal and exercise proteinuric urines give a double $\gamma$-line, in the latter case up to excretion rates of $5.1 \mathrm{mg}$ per minute, this being the highest level achieved in the swimmers under study and overlapping the range of the postural and nephrotic group. The urinary $\gamma$-globulin of 
nephrosis produces bands which may vary between patients and may remain double up to high levels of protein excretion.

The significance of multiple $\gamma$-globulin precipitin lines in immunoelectrophoretic patterns of serum has recently been investigated by Edelman and associates (31), who showed immunologic corre- spondence between the two components of a double line and the precipitin lines produced by the two main fragments derived by papain digestion of human serum $\gamma$-globulin. In immunoelectrophoretic studies of normal urine, Grant (6) noted the presence of double precipitin lines for $\gamma$-globulin and suggested that these probably indicated the

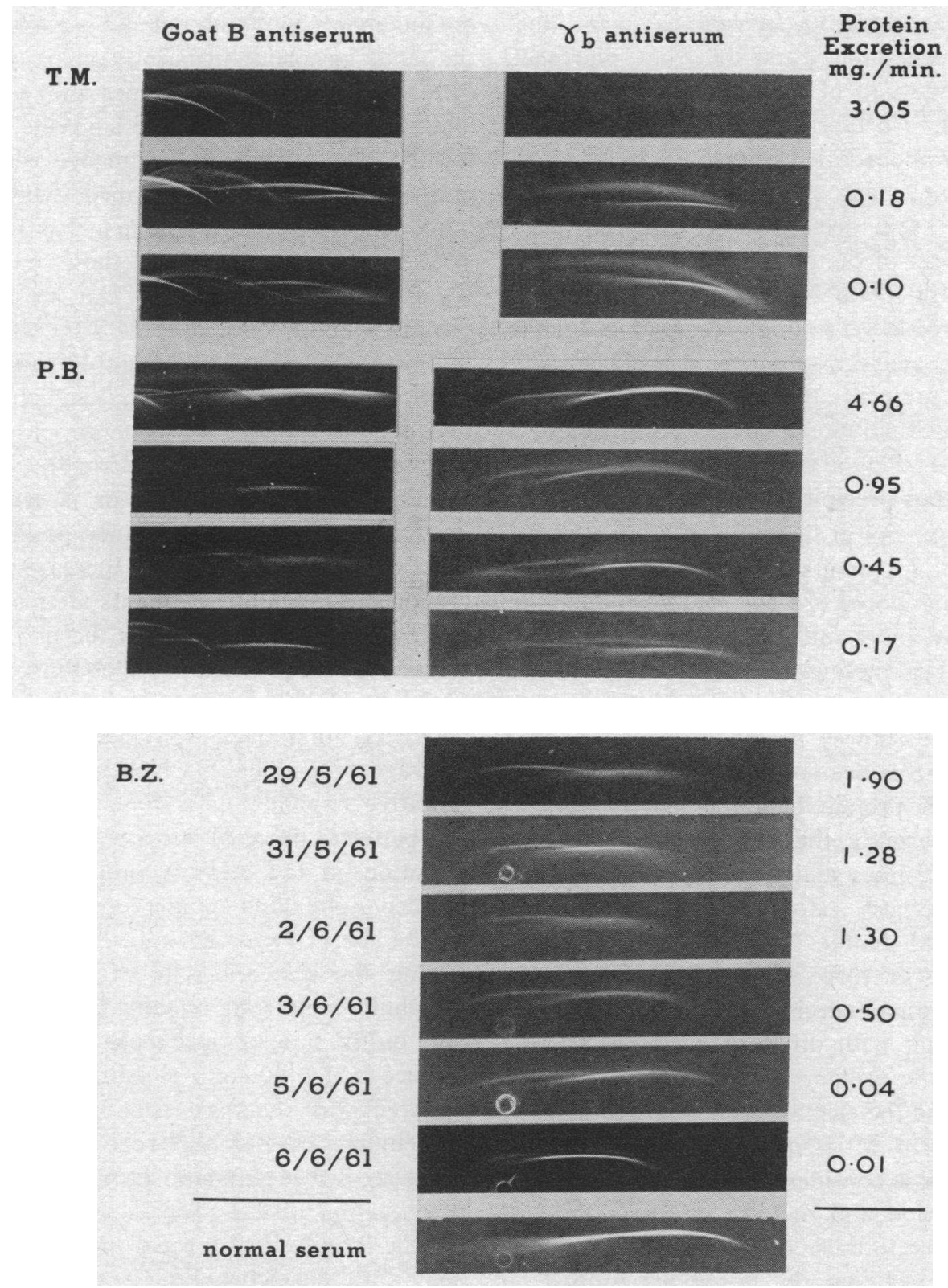

FIG. 12. IMMUNOELECTROPHORESIS OF URINARY PROTEIN FROM THREE CHILDREN WITH NEPHROSIS AT VARIOUS RATES OF PROTEIN EXCRETION, WITH ANTISERUM TO WHOLE HUMAN SERUM AND TO $\boldsymbol{\gamma}$-GLOBULIN. Splitting of gamma bands does not appear to be restricted to protein excreted at low rates and differs from postural proteinuric urines excreted at similar rates. 
presence of small fragments of $\gamma$-globulin, a hypothesis which has since been confirmed.

It seems likely that the double lines in exercise urine and in certain nephrotic urines are also indicative of the presence of $\gamma$-globulin fragments in substantial amount. Preliminary studies of the $\gamma$-globulins prepared by electrophoresis and DEAE cellulose chromatography suggest that the molecular size of the fragments in exercise urine and normal urine are similar, and that they represent the larger proportion of the $\gamma$-globulin molecules in these urines. Furthermore, it appears that they are different from lordotic urinary $\gamma$-globulin which is of larger molecular size. Rowe and Soothill (32) have recently demonstrated that the mean molecular weight of the protein is lower for exercise proteinuria than for postural proteinuria. However, when only a single $\gamma$-globulin line is visible on immunoelectrophoresis, a small amount of $\gamma$-globulin fragments may nevertheless be present, but in such minute quantity relative to $7 \mathrm{~S}$ $\gamma$-globulin that they are not concentrated sufficiently to form a precipitin line.

$\gamma$-Globulin precipitin lines in series may represent denatured fragments, as suggested by Patté, Baldassaire and Loret (7) for composite albumin lines of similar appearance. This may be the explanation of the findings in the lordotic urines from Subject I.S., although, as previously noted, this girl's urine showed a pattern similar to that of other lordotic urines on various occasions when the methods of protein handling and concentration were apparently the same. The difference between double lines and lines in series may be difficult to interpret. For instance, the mobility relationship and degree of lateral separation between the two or three $\gamma$-lines in normal urine (Figure 9B) and exercise urine (Figure 10A) varies somewhat with different antisera. In the case of nephrotic urinary $\gamma$-globulin (Figure 12), the difference in the electrophoretic mobility of the two $\gamma$-bands of T.M. is quite pronounced. Furthermore, there is considerable variation in the apparent proportion and mobility of the $\gamma$-lines of T.M. in contrast to those of P.B. and B.Z. These variations suggest that the fragments formed on cleavage of the $\gamma$-globulin molecule may differ in relative proportion and properties in the various proteinurias.

Scheidegger and Buzzi (33) have demonstrated that normal $\gamma$-globulin has at least four groupings which determine antigenic properties. The variable antibody response of different animals to these groupings will determine the number of lines which may be produced in interface reactions and the distance between them. This may well explain the variations in immunoelectrophoretic patterns with different antisera observed here and in the studies of Goodman (34), who noted $5 \gamma$-globulin precipitin bands in normal urinary protein. Our finding of three distinct precipitin lines with normal urine and two with exercise urine suggests that, in the former, two $\gamma$-globulin fragments with different antigenic specificity are formed, whereas in the latter only one type of fragment has been demonstrated. The relationship of these moieties to the $\gamma$-globulin fragments which can be produced in vitro is not clear.

Berggard (35) has recently demonstrated a small moiety in normal serum designated $\gamma_{\mathrm{L}}$-globulin. Whether this is a cleavage product of $7 \mathrm{~S}$ $\gamma$-globulin, as suggested by Franklin (4) and by Webb and colleagues (13), or is synthesized de novo is unknown. The former possibility might seem credible in view of the increased rate of excretion of $\gamma$-globulin fragments after exercise.

However, the difference in the precipitin bands formed by the urinary $\gamma$-globulins of different nephrotic children (noted also by us in acute nephritis) might suggest variations in the types of cleavage of $\gamma$-globulin which may occur. An alternative explanation is that these variations of the patterns in renal disease may reflect only a variation in the relative proportion of $7 \mathrm{~S}$ and smaller $\gamma$-globulins being excreted.

The site of formation as well as the factors affecting the size and rate of excretion of these $\gamma$-globulin fragments remains obscure. Based not only on the time of occurrence but also on the difference in the type of $\gamma$-globulin excreted, it seems apparent that exercise proteinuria and postural proteinuria arise by different mechanisms. It is postulated that exercise proteinuria may be an accentuation of the process which is responsible for the infinitesimal normal protein loss, although some differences between them are evident.

\section{SUM MARY}

The proteins excreted in "normal" exercise, postural, and nephrotic urines have been studied 
by immunoelectrophoresis to determine the nature of the $\gamma$-globulins. In contrast to the single precipitin line developed by the $\gamma$-globulin of normal serum and postural proteinuria, double or triple lines or lines in series are formed by the $\gamma$-globulins in the other three types of proteinuria.

The findings suggest that, with respect to multiple bands, the $\gamma$-globulins are excreted as fragments of small size, that exercise proteinuria may be an accentuation of the process responsible for normal proteinuria, and that relatively large amounts of the $\gamma$-globulin fragments may be excreted in certain cases of nephrotic syndrome.

\section{ACKNOWLEDGMENT}

Appreciation is expressed for assistance and advice given by G. E. Connell, Margaret de Wolfe, Donald Mills, S. H. Jackson, H. Armstrong, and J. H. Ebbs. Furthermore, we are grateful for the cooperation of the University of Toronto swimming team.

\section{REFERENCES}

1. Mörner, K. A. H. Untersuchungen über die Proteinstoffe und die eiweissfällenden Substanzen des normalen Menschenharns. Skand. Arch. Physiol. $1895,6,332$.

2. Stewart, T. G. Clinical Lectures on Important Symptoms, Fasciculus II, on Albuminuria. Edinburgh, Bell and Bradfute, 1888.

3. Rigas, D. A., and Heller, C. G. The amount and nature of urinary proteins in normal human subjects. J. clin. Invest. 1951, 30, 853.

4. Franklin, E. C. Physicochemical and immunologic studies of gamma globulins of normal human urine. J. clin. Invest. 1959, 38, 2159.

5. Grant, G. H. Proteins of normal urine. II. From the urinary tract. J. clin. Path. 1959, 12, 510.

6. Grant, G. H. The proteins of normal urine. J. clin. Path. 1957, 10, 360.

7. Patté, J. C., Baldassaire, G., and Loret, J. Etude immuno-électrophorétique des protéinuries normale et pathologiques. Rev. franç. Et. clin. biol. 1958, 3, 960.

8. Biserte, G., Breton, A., and Havez, R. Etude électrophorétique et immunologique des proteins urinaires chez l'enfant sain et au cours des nephropathies. Arch. franç. Pédiat. 1959, 16, 634.

9. Keutel, H. J., Hermann, G., and Licht, W. Immunoelektrophoretische Untersuchungen über den serumdentischen Anteil der Harnkolloide und ihre Bedentung bei der Harnsteinbildung. Clin. chim. Acta 1959, 4, 665.

10. Berggard, I. Studies on the plasma proteins in normal human urine. Clin. chim. Acta 1961, 6, 413.

11. Bourrillon, R., and Kaplan, J. C. Les glycoprotéines de l'urine normale. I. Répartition des constituants glucidiques des glycoprotéines au cours du fractionnement. Clin. chim. Acta 1960, 5, 732.

12. Jahnke, K., and Scholtan, W. Zum Mechanismus der Proteinurie. Dtsch. Arch. klin. Med. 1953, 200, 821.

13. Webb, T., Rose, B., and Sehon, A. H. Biocolloids in normal human urine. II. Physiochemical and immunochemical characteristics. Canad. J. Biochem. 1958, 36, 1167.

14. Slater, R. J., O’Doherty, N. J., and DeWolfe, M. S. Studies on human proteinuria. I. The mechanism of postural proteinuria. Pediatrics 1960, 26, 190.

15. Ulzmann, R., quoted by Medes, G., and Neemes, M. Orthostatic proteinuria in The Kidney in Health and Disease, H. Berglund and G. Medes, Eds. Philadelphia, Lea and Febiger, 1935, p. 462.

16. Lowgren, E. Studies on benign proteinuria. Acta med. Scand. 1955, 151, suppl. 300.

17. Hartmann, L., Lagrue, G., and Moretti, J. Confrontation du syndrome néphrotique et de la protéinurie lordotique, études physiques et immunologiques des protéines sériques et urinaires. Rev. franç. Et. clin. biol. 1958, 3, 1052.

18. von Leube, quoted in Albuminuria in health. Lancet 1878, 1, 503.

19. Blake, J. B., and Larrabee, R. C. Observations upon long-distance runners. Boston med. surg. J. 1903, 148, 195.

20. Collier, W. Functional albuminuria in athletes. Brit. med. J. 1907, 1, 4.

21. Volhard, F. Handbuch der Inneren Medizin, 2nd ed., L. Mohr and R. Staehelein, Eds. Berlin, Springer, 1931, vol. 6, p. 854.

22. Gardner, K. D., Jr. "Athletic pseudonephritis"; A1teration of urine sediment by athletic competition. J. Amer. med. Ass. 1956, 161, 1613.

23. Nebda1, J., and Seliger, V. Electrophoretic analysis of exercise proteinuria. J. appl. Physiol. 1958, 13, 244.

24. Johnson, G. Cases of temporary albuminuria, the result of cold bathing. Trans. clin. Soc. Lond. 1874, 7, 42.

25. Kunkel, H. G., and Slater, R. J. Zone electrophoresis in a starch supporting medium. Proc. Soc. exp. Biol. (N. Y.) 1952, 80, 42.

26. Jackson, S. H., Farmer, A. W., Slater, R. J., and DeWolfe, M. S. The resolution of urinary or serum proteins by chromatography on Deae cellulose columns with particular reference to urinary proteins after thermal burns. Canad. J. Biochem. 1961, $39,881$.

27. Scheidegger, J. J. Une micro-méthode d'immunoélectrophorèse. Int. Arch. Allergy 1955, 7, 103.

28. Wieme, R. J. An improved technique of agar-gel electrophoresis on microscopic slides. Clin. chim. Acta 1959, 4, 317.

29. Stevenson, G. T. Personal communication.

30. White, H. L., and Rolf, D. Effects of exercise and of some other influences on the renal circulation in man. Amer. J. Physiol. 1948, 152, 505. 
31. Edelman, G. M., Heremans, J. F., Heremans, M-Th., and Kunkel, H. G. Immunological studies of human $\gamma$-globulin. Relation of the precipitin lines of whole $\gamma$-globulin to those of the fragments produced by papain. J. exp. Med. 1960, 112, 203.

32. Rowe, D. S., and Soothill, J. F. The proteins of postural and exercise proteinuria. Clin. Sci. 1961, 21, 87.

33. Scheidegger, J. J., and Buzzi, C. Etude immunoélectrophorétique des gamma-globulines: Identification de plusieurs déterminants antigéniques grâce aux protéins de Bence-Jones et aux sérums de myélomes. Rev. franç. Et. clin. biol. 1957, 2, 895.

34. Goodman, H. Immunoelectrophoretic studies of the gamma globulins in normal urine and in urine from patients with the nephrotic syndrome. (Proc. Twelfth Annual Conf. on the Nephrotic Syndrome.) New York, National Kidney Disease Foundation, 1961, p. 245.

35. Berggard, I. On a $\gamma$-globulin of low molecular weight in normal human plasma and urine. Clin. chim. Acta 1961, 6, 545. 